J Am Chem Soc. 2019 June 12; 141(23): 9365-9372. doi:10.1021/jacs.9b03435.

\title{
Duplex Stem Replacement with bPNA+ Triplex Hybrid Stems Enables Reporting on Tertiary Interactions of Internal RNA Domains
}

\author{
Shiqin Miao ${ }^{1}$, Yufeng Liang ${ }^{1}$ \\ Ila Marathe ${ }^{2}$ \\ Jie Mao' ${ }^{1}$, Chris DeSantis ${ }^{1}$, Dennis Bong ${ }^{*}, 1$ \\ ${ }^{1}$ Department of Chemistry and Biochemistry, Columbus, Ohio 43210, United States \\ ${ }^{2}$ Department of Microbiology and the Center for RNA Biology, The Ohio State University, $100 \mathrm{~W}$. \\ 18th Avenue, Columbus, Ohio 43210, United States
}

\section{Abstract}

We report herein the synthesis and DNA/RNA binding properties of bPNA+, a new variant of bifacial peptide nucleic acid (bPNA) that binds oligo T/U nucleic acids to form triplex hybrids. By virtue of a new bivalent side chain on bPNA+, similar DNA affinity and hybrid thermostability can be obtained with half the molecular footprint of previously reported bPNA. Lysine derivatives bearing two melamine bases $\left(\mathrm{K}^{2 \mathrm{M}}\right)$ can be prepared on multigram scale by double reductive alkylation with melamine acetaldehyde, resulting in a tertiary amine side chain that affords both peptide solubility and selective base-triple formation with $4 \mathrm{~T} / \mathrm{U}$ bases; the Fmoc- $\mathrm{K}^{2 \mathrm{M}}$ derivative can be used directly in solid phase peptide synthesis, rendering bPNA+ conveniently accessible. A compact bPNA+binding site of two U6 domains can be genetically encoded to replace existing 6 bp stem elements at virtually any location within an RNA transcript. We thus replaced internal 6 bp RNA stems that supported loop regions with 6 base-triple hybrid stems using fluorophorelabeled bPNA+. As the loop regions engaged in RNA tertiary interactions, the labeled hybrid stems provided a fluorescent readout; bPNA+ enabled this readout without covalent chemical modification or introduction of new structural elements. This strategy was demonstrated to be effective for reporting on widely observed RNA tertiary interactions such as intermolecular RNARNA kissing loop dimerization, RNA-protein binding, and intramolecular RNA tetralooptetraloop receptor binding, illustrating the potential general utility of this method. The modest $6 \mathrm{bp}$ stem binding footprint of bPNA+ makes the hybrid stem replacement method practical for noncovalent installation of synthetic probes of RNA interactions. We anticipate that bPNA+ structural probes will be useful for the study of tertiary interactions in long noncoding RNAs.

\section{Graphical Abstract}

\footnotetext{
*Corresponding Author: bong.6@osu.edu.

Supporting Information

The Supporting Information is available free of charge on the ACS Publications website at DOI: 10.1021/jacs.9b03435.

Detailed experimental procedures, sequences, chemical structures, compound characterization, fluorescence spectra, and additional biophysical data for bPNA hybrids (PDF)

The authors declare no competing financial interest.
} 


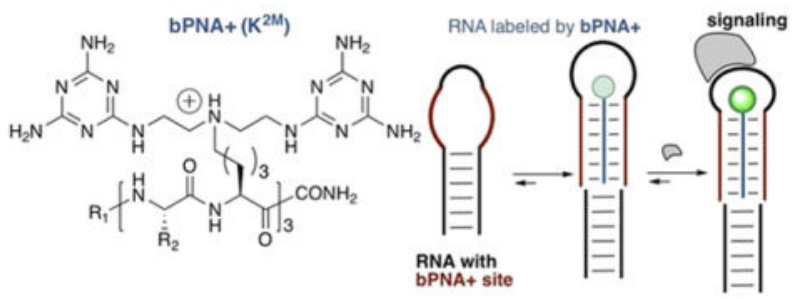

\section{INTRODUCTION}

Studies on triazine assembly ${ }^{1-5}$ with native bases ${ }^{5-8}$ and as artificial base pairs ${ }^{9-11}$ in PNA ${ }^{12}$ revealed that monosubstituted melamine $(\mathrm{M})$ is "bifacial"13-17 with regard to base recognition; melamine can dock two equivalents of thymine $(\mathrm{T})$ or uracil $(\mathrm{U})$ via the Watson-Crick face to form a TMU or UMU base triple ${ }^{18}$ when displayed on smallmolecule, ${ }^{18,19}$ peptide, ${ }^{20-25}$ peptoid, ${ }^{26}$ and polymer ${ }^{8,22}$ scaffolds, reminiscent of a TAT or UAU base triple. ${ }^{27-29}$ An unstructured oligo T/U loop may be folded into a triplex hybrid stem with a class of peptides that side-chain-display melamine, called bifacial peptide nucleic acid (bPNA) ${ }^{20}$ Triplex hybrid bPNA stems can functionally replace duplex stems in a range of noncoding folded nucleic acids, suggesting that stem replacement is minimally perturbative. ${ }^{24}$ Herein, we examine the extent to which triplex hybridization can be used to site-specifically install fluorophore reporters of RNA loop tertiary contacts at internal sites by genetically encoding oligo-U domains for selective targeting using a new triplex-forming peptide we call bPNA+. This method for labeling internal RNA loops could be a convenient biochemical complement to chemical modification of RNA, ${ }^{30,31}$ which can be technically challenging or sequence-limited. Our prior work (Figure 1) indicated that bPNAs containing 10 lysine residues derivatized with a single melamine $\left(\mathrm{K}^{\mathrm{M}}\right)$ could form a complex with oligo-T DNA that had good thermal stability $\left(T_{\mathrm{m}} \sim 60^{\circ} \mathrm{C}\right)$, while hybrids with $6 \mathrm{~K}^{\mathrm{M}}$ residues had $T_{\mathrm{m}} \sim 38{ }^{\circ} \mathrm{C} .{ }^{20} \mathrm{We}$ considered the possibility of using the thermally stable 10 repeat $\mathrm{K}^{\mathrm{M}}$-bPNA to site-specifically install reporter labels in long noncoding (lnc)RNAs by replacing existing duplex stems with U-domains that could triplex hybridize with probefunctionalized bPNAs. However, the need to identify $10 \mathrm{bp}$ stems for replacement within IncRNAs of interest was a limitation; 6 bp stems are more common, but stability of the 6mer $\mathrm{K}^{\mathrm{M}}$-bPNA hybrids was significantly lower. Based on our recent finding that two melamine rings on a tren scaffold $(\mathrm{t} 2 \mathrm{M})$ exhibited micromolar affinity to $\mathrm{T}_{4} / \mathrm{U}_{4}$ sites in DNA/RNA, ${ }^{19}$ we hypothesized that peptide side chain installation of the $2 \mathrm{M}$ motif could potentially lead to new higher affinity binders when displayed multivalently. Additionally, it was expected that the protonated tertiary amine side chain would provide favorable electrostatic interactions for nucleic acid binding. In this work, we describe the synthesis of this new peptide design, which we call bPNA+ due to its cationic ammonium side chain at neutral $\mathrm{pH}$. Further, we evaluate the DNA and RNA binding properties of bPNA+ and demonstrate its utility for installing fluorescent reporters of tertiary RNA interactions at internal locations within folded RNA via replacement of 6 bp stems with bPNA+ triplex hybrid stems that are roughly equivalent in size. 


\section{RESULTS AND DISCUSSION}

To determine the optimum side chain length for DNA binding, peptides were prepared bearing either diaminobutyric acid (B), ornithine $(\mathrm{O})$, or lysine $(\mathrm{K})$ with 2, 3, and 4 carbon linkers between the $\delta$-carbon and the side chain primary amine, respectively. These peptides were subjected to reductive alkylation ${ }^{32-34}$ with melamine acetaldehyde to yield lysine $\left(\mathrm{K}^{2 \mathrm{M}}\right)$, ornithine $\left(\mathrm{O}^{2 \mathrm{M}}\right)$, and diaminobutyric acid $\left(\mathrm{B}^{2 \mathrm{M}}\right)$ at alternate positions (Scheme 1). Interestingly, melamine acetaldehyde $\mathbf{1}$ appears to exist as a cyclic hemiaminal-type structure in DMSO but nevertheless reacts as expected in the alkylation (Supporting Information). Our initial studies focused on hexapeptide cores of 3 dyad repeats with 2Mbearing residues at alternate positions with native amino acid residues (glutamate or serine). As each peptide has 6 melamine rings displayed, we tested binding to $\mathrm{T}_{6} \mathrm{C}_{4} \mathrm{~T}_{6}$ DNA by thermal denaturation (UV melt), differential scanning calorimetry (DSC), and fluorescence anisotropy. Interestingly, while the $\mathrm{O}^{2 \mathrm{M}}$ and $\mathrm{K}^{2 \mathrm{M}}$ peptides exhibited similar melt transitions $\left(T_{\mathrm{m}} \sim 60^{\circ} \mathrm{C}\right)$, the $\mathrm{B}^{2 \mathrm{M}}$ peptides were less thermally stable by $\sim 10{ }^{\circ} \mathrm{C}$, indicating a significant loss of function when the side chain is shortened by one atom (Table 1). Both zwitterionic glutamate and cationic serine peptides were easily soluble, though the serine peptides $\left(\mathrm{SK}^{2 \mathrm{M}}\right)_{3}$ exhibited stronger DNA binding, presumably due to favorable electrostatics (Table 1). This trend held for longer peptides with $\left(\mathrm{SK}^{2 \mathrm{M}}\right)_{5}$ binding DNA more tightly than and $\left(\mathrm{EK}^{2 \mathrm{M}}\right)_{5}$. To confirm that the melamine rings drive selective binding by base triple formation rather than electrostatics, the $\mathrm{p} K_{\mathrm{A}}$ of a model $2 \mathrm{M}$ compound was determined. A $\delta$-linked ammonium ion is known to decrease the $\mathrm{p} K_{\mathrm{A}}$ of the protonated monoalkyl melamine from 5.3 to $4.5,{ }^{35}$ and the close linkage of two melamines results in a further apparent $\mathrm{p} K_{\mathrm{A}}$ decrease to 3.9 (Supporting Information). Thus, the melamine rings in $\mathrm{K}^{2 \mathrm{M}}$ are even less basic than $\mathrm{K}^{\mathrm{M}}$, resulting in neutral melamine and a bPNA+ charge state of at most $3+$ at $\mathrm{pH} 7.4$, deriving from protonation of the 3 tertiary amine side chains. The contribution of nonspecific electrostatic binding was further tested by preparation of $\left(\mathrm{SK}^{2 \mathrm{M}-\mathrm{Me}}\right)_{3}$, which has identical charge but hydrogen bond donors blocked by tetramethylation. The ( $\left.\mathrm{SK}^{2 \mathrm{M}-\mathrm{Me}}\right)_{3}$ peptide trication does not detectably bind DNA under the same conditions (Supporting Information), suggesting that electrostatics work cooperatively with base-triple formation to enhance binding. It was qualitatively obvious from the binding curves and $T_{\mathrm{M}}$ measurements that S-bPNA+ peptides bind more tightly to DNA than the zwitterionic E-bPNA+ peptides (Figure 2, Table 1), though accurate determination of SbPNA + affinity was technically challenging due to early binding saturation and concentration detection limits. It was also clear that all DNA-bPNA+ hybrid complexes were more thermally stable than with the previously reported bPNA, $\left(\mathrm{EK}^{\mathrm{M}}\right)_{6}$, which similarly has 6 melamine rings but lacks bivalent presentation and is negatively charged overall (Table 1).

With this overview of the DNA binding landscape, we chose to focus our attention on the $\left(\mathrm{SK}^{2 \mathrm{M}}\right)_{3}$ bPNA+ for further studies on RNA binding and readout of RNA tertiary

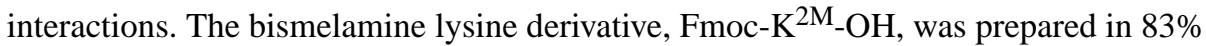
isolated yield on multigram scale via an optimized reductive alkylation procedure from commercially available Fmoc-Lys(Boc)-OH and used in solid phase peptide synthesis of bPNA+ (Scheme 1, Supporting Information). Notably, while the hexa- and decapeptide cores $\left(\mathrm{SK}^{2 \mathrm{M}}\right)_{3}$ and $\left(\mathrm{SK}^{2 \mathrm{M}}\right)_{5}$ were easily water-soluble, the analogous $\left(\mathrm{SK}^{\mathrm{M}}\right)$ bPNAs were 
difficult to dissolve and purify, presumably due to lack of an ionizable side chain. The $\left(\mathrm{SK}^{2 \mathrm{M}}\right)_{3}$ peptide core was $N$-terminally modified with dyes (carboxy-fluorescein $(\mathrm{Cbf})$ and cyanine (Cy3, Cy5)) for binding and fluorescence reporting studies. To study RNA binding and bPNA+ signaling of tertiary contacts, we chose to modify a well-studied system from the ColE1 plasmid, ${ }^{36,37}$ which regulates transcription in part through the formation of an RNA hairpin heterodimeric kissing complex that is subsequently stabilized by binding a native protein, Rop. The binding of isolated RNA hairpins from the ColE1 plasmid as well as Rop binding to the hairpin heterodimer have been studied extensively by Tomizawa and coworkers. ${ }^{37,38}$ Further, the ColE1 RNA kissing loop and variants were among the first RNA systems to be structurally characterized by Crothers and coworkers. ${ }^{39,40}$ The RNA-protein interaction between the kissing loop dimer and Rop protein has also been extensively studied; ${ }^{36}$ this system has thus yielded foundational information regarding RNA tertiary interactions. The ColE1 hairpins RNA1 and RNA2, which together form a heterodimer via complementary base-pairing between the 7 nucleotide loop regions, were redesigned to insert $\mathrm{U}_{6} / \mathrm{U}_{6}$ domains in between the 6-7 bp duplex stem and the 7-nt loop recognition element (Figure 3). Both $\mathrm{U}_{6}$-hairpin RNAs derived from RNA1 and RNA2 shifted cleanly on gel upon complexation with fluorophore-tagged $\left(\mathrm{SK}^{2 \mathrm{M}}\right)_{3}$ with apparent $K_{\mathrm{d}}$ in the low nanomolar range (Figure 3, Supporting Information). Interestingly, although the RNA1-U6 hairpin alone exhibited a broad melting with two apparent transitions due to the folded stem and extended loop structure, bPNA+ binding resulted in a single, well-defined thermal transition $\left(T_{\mathrm{m}}=60^{\circ} \mathrm{C}\right)$, indicative of a cooperative folding of the RNA duplex stem with bPNA+ triplex hybrid domain. Further, while the overall change in $T_{\mathrm{m}}$ was modest, peptide complexation resulted in considerable qualitative sharpening of the transition and increase in $\mathrm{UV}$ absorbance change, in line with expectations based on $\mathrm{K}^{\mathrm{M}}$-bPNA.

With RNA-bPNA+ binding confirmed, the $\left(\mathrm{SK}^{2 \mathrm{M}}\right)_{3}$ peptide core was capped with $\mathrm{Cy} 3$ or Cy5 dyes to test the extent to which labeled RNA loops could provide fluorescence reporting of loop interactions. The Cy-bPNA+ peptides were triplex hybridized with RNA1-U6 and RNA2-U6 in a single mixing experiment, which is expected to result in random sorting of the two bPNA+ $\left(\mathrm{Cy} 3-\left(\mathrm{SK}^{2 \mathrm{M}}\right)_{3}\right.$ and $\left.\mathrm{Cy} 5-\left(\mathrm{SK}^{2 \mathrm{M}}\right)_{3}\right)$ with the two U6-RNAs. Under conditions reported for RNA kissing loop complex formation (5-10 $\mathrm{mM} \mathrm{Mg}^{2}+$ buffer), an RNA dimer was observed by gel shift and supported by FRET-mediated $\mathrm{Cy} 3$ quenching and $\mathrm{Cy} 5$ emission in solution and on gel (Figure 4). This simple experiment demonstrates the feasibility of labeling internal RNA loop interactions via bPNA+ triplex hybridization. The randomly sorted binding process is convenient, and its use sidesteps a technical challenge in site selection by bPNAs. Previously, we studied an RNA hairpin system with both U6 and U10 binding sites along with $\mathrm{Cy} 3 / \mathrm{Cy} 5$ labeled $\left(\mathrm{SK}^{2 \mathrm{M}}\right)_{3}$ and $\left(\mathrm{SK}^{2 \mathrm{M}}\right)_{5}$ peptides to exploit known preferences for length matching between bPNA and nucleic acid binding site. ${ }^{2,25}$ However, while the longer $\left(\mathrm{SK}^{2 \mathrm{M}}\right)_{5}$ peptide did indeed prefer the U10 site, so did the shorter $\left(\mathrm{SK}^{2 \mathrm{M}}\right)_{3}$ peptide. Furthermore, while bPNA+ binding to U6 and U10 RNA was clean under the experimental conditions, higher concentrations resulted in the formation of lower mobility complexes, presumably due to nonhairpin forms. These higher gel bands were more prevalent with the longer U10-interface and high magnesium concentration, underscoring the need for a more compact, well-behaved U6 RNA site enabled by the new bPNA+ scaffold. Overall, despite potential signal loss deriving from random sorting, the use of two 
similar U6 RNA sites with $\left(\mathrm{SK}^{2 \mathrm{M}}\right)_{3}$ peptides conveniently delivers a significant fluorescence read-out for RNA loop-loop interactions.

While RNA kissing loop formation was clearly reported by FRET between two labeled triplex hybrid stems, we were interested in reporting stem-loop interactions with native, unlabeled partners. We observed that triplex hybridization of Cy-modified $\left(\mathrm{SK}^{2 \mathrm{M}}\right)$ peptides with U-sites in RNA resulted in a significant turn-on of emission intensity (60-100x), similar to prior reports of fluorogenic binding of $\mathrm{Cy} 3$ and methylated $\mathrm{Cy} 3$ dyes to DNA quadruplexes. ${ }^{41}$ Interestingly, the $\left(\mathrm{EK}^{\mathrm{M}}\right)$ bPNAs previously studied exhibited a much weaker (2-5x) fluorogenic effect upon binding nucleic acid. Though the origins of this difference are still under investigation, we hypothesized that further changes in emission might be observable if the peptide-complexed RNA host was perturbed through tertiary interactions. Gratifyingly, a significant 2-3-fold dose-dependent fluorescent turn-on of $\mathrm{N}$ terminal bPNA+ cyanine dyes is observed when a [RNA1-U6.Cy5-( $\left.\mathrm{SK}^{2 \mathrm{M}}\right)_{3}$ ] triplex stemloop engages with the wild-type RNA2 stem-loop to form an RNA kissing loop heterodimer. Further, an additional dose-dependent $\sim 7$-fold increase in emission is observed upon Rop protein binding to the hybrid RNA kissing loop complex for an overall signal increase of $~ 20$-fold, indicating RNA-protein complexation of a labeled stem-loop (Figure 5). Enhanced fluorescence emission from the bPNA+ triplex hybrid stem loop upon binding RNA and protein was observed both in solution and on gel, confirming that the increased emission comes from the tertiary interactions. This proof of concept system demonstrates the potential for bPNA+-modified stem-loops to serve as reporters for both RNA-RNA and RNA-protein tertiary interactions.

To broaden the scope of bPNA+ labeling, we designed an RNA system with an intramolecular tertiary contact between two different internal secondary structures, both labeled by stem replacement. Development of a method to genetically encode sites for internal RNA labeling would facilitate structure-function studies on IncRNAs and complement known chemoenzymatic labeling strategies ${ }^{30}$ and duplex hybridization approaches. ${ }^{42}$ Notably, bPNA+ stem replacement is a minor structural perturbation of an existing structural element, unlike duplex strategies ${ }^{42}$ that add a new structural element within folded lncRNA. We tested this notion using a well-studied intramolecular tertiary interaction between a GAAA tetraloop (TL) and $11 \mathrm{nt}$ tetraloop receptor (TLR) found in several domains of group I and group II introns as well as RNase $\mathrm{P}^{43,44}$ that has proved useful for engineering RNA structures. ${ }^{45}$ This widely observed native interaction requires 5$10 \mathrm{mM} \mathrm{Mg}^{2+}$ to form in in vitro experiments. Based on prior reports, ${ }^{45,46}$ we designed TLTLR sites on adjacent RNA helices with a short linker and U6-stem replacement and insertion at the helices supporting the TL and TLR (Scheme 2). Ikawa et al. designed a selffolding RNA system that incorporated structural elements from the Tetrahymena group I ribozyme such as the TL/TLR module and a triple helical scaffold that supports the $11 \mathrm{nt}$ TLR. This system was found to engage in a magnesium-dependent, intramolecular TL/TLR binding event, concomitant with rearrangement of the triple helix scaffold into coaxially stacked helices. ${ }^{45}$ This engineered system containing native structural features was an ideal platform to test bPNA+ reporting. Notably, P2 of this system, which supports the GAAA tetraloop, is $12 \mathrm{bp}$ long and easily accommodates $6 \mathrm{bp}$ stem replacement bPNA+ labeling. For the TLR, we chose to leave P3 undisturbed as it contains the triple helix scaffold, and 
instead inserted a U-loop for bPNA+ binding distal to P3 (Scheme 2). Thus, formation of the TL-TLR complex in this construct is expected to be undisturbed as the physical distance separating the GAAA tetraloop from the TLR has not been altered significantly, and coaxial stacking of the P2 and P3 helical subunits should proceed as designed. ${ }^{45,47}$ We maintained design simplicity by using U6 domains at both locations. Though we anticipated random distribution of bPNAs between the two sequence identical U6 sites, it is possible that the structural context of the sites creates a preferred binding site. It was not apparent if one of the two sites was preferred; the RNA construct was nonetheless incubated with Cy3 and Cy5 labeled $\left(\mathrm{SK}^{2 \mathrm{M}}\right)_{3}$ bPNA+ sequentially to allow site saturation. Gratifyingly, a FRET signal was indeed observed as a function of magnesium with maximum $\mathrm{Cy} 3$ donor quenching and Cy5 acceptor emission at $\sim 5 \mathrm{mM} \mathrm{Mg}^{2+}$, consistent with prior reports on the TL/TLR interaction (Figure 6). This result extends the scope of our bPNA labeling strategy to intramolecular RNA tertiary contacts, including not only internal loops but a ubiquitous tetraloop receptor motif.

\section{CONCLUSIONS}

We synthesized and evaluated a family of new bPNA peptides called bPNA+ that display two base-triple forming melamine rings per side chain on a tertiary amine center that is cationic via protonation at $\mathrm{pH}$ 7.4. This charged residue affords peptide solubility, allowing use of neutral side chain residues at non-base-tripling positions. We demonstrated that the new $\mathrm{K}^{2 \mathrm{M}}$ bPNA+ peptide scaffold with a 6 residue core can bind oligo T/U sequences to form triplex stem-loop hybrids with exceptional thermal stability comparable to that of 20 residue $\mathrm{K}^{\mathrm{M}} \mathrm{bPNA}^{20}$ and conventional $\mathrm{PNA}^{48}$ but with roughly half the molecular footprint. Though highly stable synthetic duplex hybrids are accessible via scaffolds such as mini-PEG $\delta$-PNA ${ }^{49}$ or locked nucleic acids, ${ }^{50,51}$ all bPNAs uniquely bind unstructured oligo T/U domains to form triplex hybrid stems that can functionally replace existing duplex stems in folded RNAs. ${ }^{24}$ Further, like $\mathrm{K}^{\mathrm{M}}$-bPNA, $\mathrm{K}^{2 \mathrm{M}}$-bPNA+ utilizes an $\delta$-peptide backbone, and the base-tripling amino acid, $\mathrm{K}^{2 \mathrm{M}}$, can be conveniently prepared on multigram scale from commercially available lysine derivatives and isolated without column chromatography, rendering bPNA+ accessible through straightforward synthetic manipulation and conventional SPPS. With bPNA+ in hand, folded RNAs of interest may be labeled at a genetically encoded internal sites by the replacement of a modestly sized 6bp stem with a 6 base-triple hybrid stem containing modified bPNA+ such as Cy5-(SK $\left.{ }^{2 \mathrm{M}}\right)_{3}$. Stem replacement thus can site specifically install fluorescent probes without introduction of new structural elements, unlike internal duplex hybridization. ${ }^{42,52}$ Potentially, any 6 bp stem proximal to a region engaged in a tertiary contact could be labeled via stem replacement to enable a reporter of tertiary contacts. Herein, we demonstrated that this method could be used to obtain fluorescent read-out of common RNA tertiary interactions such as RNA-RNA kissing loop formation, RNA-protein, and tetraloop/tetraloop receptor binding. This biochemical method for labeling internal RNA loops via targeting to a compact, genetically encoded binding site is a technically convenient alternative (if bPNA is available) to covalent chemical modification of RNA, ${ }^{30,31}$ which requires specialized expertise or may be limited to specific sequences. Furthermore, the stem replacement method for probe installation at an internal site may be combined with established methods for RNA end-labeling, including 
duplex hybridization, that would facilitate preparation of double-labeled RNAs. ${ }^{42,52} \mathrm{We}$ anticipate that this method could complement existing approaches to RNA labeling and be applied to a broad range of systems to help elucidate lncRNA biochemistry.

\section{Supplementary Material}

Refer to Web version on PubMed Central for supplementary material.

\section{ACKNOWLEDGMENTS}

This work was supported in part by funding from the National Institutes of Health (GM111995-01A1 to D.B.), NASA (GRT00044810 to D.B.), and the NSF (DMR 1802432 to D.B.). S.M. acknowledges fellowship support from the Center of RNA Biology, OSU. I.M. (Laboratory of Venkat Gopalan, OSU) made the initial observation of increased cyanine dye emission upon binding of Cy3-(SK $\left.{ }^{2 \mathrm{M}}\right)$ to U-sites in folded RNA. I.M. acknowledges support from NIH (GM120582 to Gopalan) and the Pelotonia Fellowship Program. We thank Kimberly Stephany and the Magliery Lab for generously providing Rop protein.

\section{REFERENCES}

(1). Whitesides GM; Simanek EE; Mathias JP; Seto CT; Chin D; Mammen M; Gordon DM Noncovalent Synthesis: Using Physical-Organic Chemistry To Make Aggregates. Acc. Chem. Res 1995, 28, 37-44.

(2). Oshovsky GV; Reinhoudt DN; Verboom W Supra-molecular Chemistry in Water. Angew. Chem., Int. Ed 2007, 46, 2366-2393.

(3). Ma M; Bong D Determinants of Cyanuric Acid and Melamine Assembly in Water. Langmuir 2011, 27, 8841-8853. [PubMed: 21688852]

(4). Cafferty BJ; Gállego I; Chen MC; Farley KI; Eritja R; Hud NV Efficient Self-Assembly in Water of Long Noncovalent Polymers by Nucleobase Analogues. J. Am. Chem. Soc 2013, 135 (7), 2447-2450. [PubMed: 23394182]

(5). Avakyan N; Greschner AA; Aldaye F; Serpell CJ; Toader V; Petitjean A; Sleiman HF Reprogramming the Assembly of Unmodified DNA with a Small Molecule. Nat. Chem 2016, 8 (4), 368-376. [PubMed: 27001733]

(6). Lange RFM; Beijer FH; Sijbesma RP; Hooft RWW; Kooijman H; Spek AL; Kroon J; Meijer EW Crystal Engineering of Melamine-Imide Complexes; Tuning the Stoichiometry by Steric Hindrance of the Imide Carbonyl Groups. Angew. Chem., Int. Ed. Engl 1997, 36 (9), 969-971.

(7). Cafferty BJ; Fialho DM; Khanam J; Krishnamurthy R; Hud NV Spontaneous Formation and Base Pairing of Plausible Prebiotic Nucleotides in Water. Nat. Commun 2016, $7,7$.

(8). Zhou Z; Bong D Small-Molecule/Polymer Recognition Triggers Aqueous-Phase Assembly and Encapsulation. Langmuir 2013, 29, 144-150. [PubMed: 23205819]

(9). Kool ET Hydrogen Bonding, Base Stacking, and Steric Effects in DNA Replication. Annu. Rev. Biophys. Biomol. Struct 2001, 30 (1), 1-22. [PubMed: 11340050]

(10). Benner SA Understanding Nucleic Acids Using Synthetic Chemistry. Acc. Chem. Res 2004, 37 (10), 784-797. [PubMed: 15491125]

(11). Hirao I; Kimoto M; Yamashige R Natural versus Artificial Creation of Base Pairs in DNA: Origin of Nucleobases from the Perspectives of Unnatural Base Pair Studies. Acc. Chem. Res 2012, 45 (12), 2055-2065. [PubMed: 22263525]

(12). Mittapalli GK; Reddy KR; Xiong H; Munoz O; Han B; De Riccardis F; Krishnamurthy R; Eschenmoser A Mapping the Landscape of Potentially Primordial Informational Oligomers: Oligodipeptides and Oligodipeptoids Tagged with Triazines as Recognition Elements. Angew. Chem., Int. Ed 2007, 46, 2470-2477.

(13). Chen H; McLaughlin LW A Janus-Wedge DNA Triplex with A-W1-T and G-W2-C Base Triplets. J. Am. Chem. Soc 2008, 130, 13190-13191. [PubMed: 18783217]

(14). Branda N; Kurz G; Lehn J-M JANUS WEDGES: A New Approach towards Nucleobase-Pair Recognition. Chem. Commun 1996, 2443-2444. 
(15). Marchi-Artzner V; Jullien L; Gulik-Krzywicki T; Lehn J-M Molecular Recognition Induced Aggregation and Fusion between Vesicles Containing Lipids Bearing Complementary Hydrogen Bonding Head-Groups. Chem. Commun 1997, 117-118.

(16). Thadke SA; Hridya VM; Perera JDR; Gil RR; Mukherjee A; Ly DH Shape Selective Bifacial Recognition of Double Helical DNA. Communications Chemistry 2018, 1 (1), 79.

(17). Shin D; Tor Y Bifacial Nucleoside as a Surrogate for Both T and A in Duplex DNA. J. Am. Chem. Soc 2011, 133, 6926-6929. [PubMed: 21495708]

(18). Arambula JF; Ramisetty SR; Baranger AM; Zimmerman SC A Simple Ligand That Selectively Targets CUG Trinucleotide Repeats and Inhibits MBNL Protein Binding. Proc. Natl. Acad. Sci. U. S. A 2009, 106, 16068-16073. [PubMed: 19805260]

(19). Mao J; DeSantis C; Bong D Small Molecule Recognition Triggers Secondary and Tertiary Interactions in DNA Folding and Hammerhead Ribozyme Catalysis. J. Am. Chem. Soc 2017, 139 (29), 9815-9818. [PubMed: 28691825]

(20). Piao X; Xia X; Bong D Bifacial Peptide Nucleic Acid Directs Cooperative Folding and Assembly of Binary, Ternary, and Quaternary DNA Complexes. Biochemistry 2013, 52, 6313-6323. [PubMed: 23964711]

(21). Zeng Y; Pratumyot Y; Piao X; Bong D Discrete Assembly of Synthetic Peptide-DNA Triplex Structures from Polyvalent Melamine-Thymine Bifacial Recognition. J. Am. Chem. Soc 2012, 134 (2), 832-835. [PubMed: 22201288]

(22). Zhou Z; Xia X; Bong D Synthetic Polymer Hybridization with DNA and RNA Directs Nanoparticle Loading, Silencing Delivery, and Aptamer Function. J. Am. Chem. Soc 2015, 137 (28), 8920-8923. [PubMed: 26138550]

(23). Xia X; Piao X; Fredrick K; Bong D Bifacial PNA Complexation Inhibits Enzymatic Access to DNA and RNA. ChemBioChem 2014, 15, 31-36. [PubMed: 24259287]

(24). Xia X; Piao X; Bong D Bifacial Peptide Nucleic Acid as an Allosteric Switch for Aptamer and Ribozyme Function. J. Am. Chem. Soc 2014, 136 (20), 7265-7268. [PubMed: 24796374]

(25). Piao X; Xia X; Mao J; Bong D Peptide Ligation and RNA Cleavage via an Abiotic Template Interface. J. Am. Chem. Soc 2015, 137 (11), 3751-3754. [PubMed: 25747470]

(26). Mao J; Bong D Synthesis of DNA-Binding Peptoids. Synlett 2015, 26 (11), 1581-1585.

(27). Malnuit V; Duca M; Benhida R Targeting DNA Base Pair Mismatch with Artificial Nucleobases. Advances and Perspectives in Triple Helix Strategy. Org. Biomol. Chem 2011, 9, 326-336. [PubMed: 21046036]

(28). Soto AM; Loo J; Marky LA Energetic Contributions for the Formation of TAT/TAT, TAT/ CGC(+), and CGC(+)/CGC(+) Base Triplet Stacks. J. Am. Chem. Soc 2002, 124, 14355-14363. [PubMed: 12452709]

(29). Noeske J; Richter C; Grundl MA; Nasiri HR; Schwalbe H; Wöhnert J An Intermolecular Base Triple as the Basis of Ligand Specificity and Affinity in the Guanine- and Adenine-Sensing Riboswitch RNAs. Proc. Natl. Acad. Sci. U. S. A 2005, 102 (5), 1372-1377. [PubMed: 15665103]

(30). Alexander SC; Busby KN; Cole CM; Zhou CY; Devaraj NK Site-Specific Covalent Labeling of RNA by Enzymatic Transglycosylation. J. Am. Chem. Soc 2015, 137 (40), 12756-12759. [PubMed: 26393285]

(31). Jahn K; Olsen EM; Nielsen MM; Tørring T; MohammadZadegan R; Andersen ES; Gothelf KV; Kjems J Site-Specific Chemical Labeling of Long RNA Molecules. Bioconjugate Chem. 2011, $22(1), 95-100$.

(32). Heemstra JM; Liu DR Templated Synthesis of Peptide Nucleic Acids via Sequence-Selective Base-Filling Reactions. J. Am. Chem. Soc 2009, 131, 11347-11349. [PubMed: 19722647]

(33). Goodwin JT; Lynn DG Template-Directed Synthesis: Use of a Reversible Reaction. J. Am. Chem. Soc 1992, 114 (23), 9197-9198.

(34). Levadala MK; Banerjee SR; Maresca KP; Babich JW; Zubieta J Direct Reductive Alkylation of Amino Acids: Synthesis of Bifunctional Chelates for Nuclear Imaging. Synthesis 2004, 2004 (11), 1759-1766. 
(35). Yin H; Feng Y; Liu H; Mu M; Fei C Insights into the Relationship between CO $\square$ Switchability and Basicity: Examples of Melamine and Its Derivatives. Langmuir 2014, 30 (33), 9911-9919. [PubMed: 25089743]

(36). Predki PF; Nayak LM; Gottlieb MB; Regan L Dissecting RNA-Protein Interactions: RNA-RNA Recognition by Rop. Cell 1995, 80 (1), 41-50. [PubMed: 7529141]

(37). Eguchi Y; Tomizawa J-I Complex Formed by Complementary RNA Stem-Loops and Its Stabilization by a Protein: Function of ColE1 Rom Protein. Cell 1990, 60, 199-209. [PubMed: 1688738]

(38). Eguchi Y; Tomizawa J-I Complexes Formed by Complementary RNA Stem-Loops: Their Formations, Structures and Interaction with ColE1 Rom Protein. J. Mol. Biol 1991, 220, 831842. [PubMed: 1715406]

(39). Lee AJ; Crothers DM The Solution Structure of an RNA Loop-Loop Complex: The ColE1 Inverted Loop Sequence. Structure 1998, 6 (8), 993-1005. [PubMed: 9739090]

(40). Marino JP; Gregorian RS, Jr; Csankovszki, G.; Crothers, D. M. Bent Helix Formation between RNA Hairpins with Complementary Loops. Science 1995, 268 (5216), 1448-1454. [PubMed: 7539549]

(41). Mohammed HS; Delos Santos JO; Armitage BA Noncovalent Binding and Fluorogenic Response of Cyanine Dyes to DNA Homoquadruplex and PNA-DNA Heteroquadruplex Structures. Artif. DNA PNA XNA 2011, 2 (2), 43-49. [PubMed: 21912726]

(42). Schmitz AG; Zelger-Paulus S; Gasser G; Sigel RKO Strategy for Internal Labeling of Large RNAs with Minimal Perturbation by Using Fluorescent PNA. ChemBioChem 2015, 16 (9), 1302-1306. [PubMed: 25872497]

(43). Costa M; Michel F Frequent Use of the Same Tertiary Motif by Self-Folding RNAs. EMBO J. 1995, 14 (6), 1276-1285. [PubMed: 7720718]

(44). Tanner MA; Cech TR An Important RNA Tertiary Interaction of Group I and Group II Introns Is Implicated in Gram-Positive RNase P RNAs. RNA 1995, 1 (4), 349-350. [PubMed: 7493313]

(45). Ikawa Y; Fukada K; Watanabe S-I; Shiraishi H; Inoue T Design, Construction, and Analysis of a Novel Class of Self-Folding RNA. Structure 2002, 10 (4), 527-534. [PubMed: 11937057]

(46). Hodak JH; Downey CD; Fiore JL; Pardi A; Nesbitt DJ Docking Kinetics and Equilibrium of a GAAA Tetraloop-Receptor Motif Probed by Single-Molecule FRET. Proc. Natl. Acad. Sci. U. S. A 2005, 102 (30), 10505-10510. [PubMed: 16024731]

(47). Cate JH; Gooding AR; Podell E; Zhou K; Golden BL; Kundrot CE; Cech TR; Doudna JA Crystal Structure of a Group I Ribozyme Domain: Principles of RNA Packing. Science 1996, 273 (5282), 1678-1685. [PubMed: 8781224]

(48). Giesen U; Kleider W; Berding C; Geiger A; Orum H; Nielsen PE A Formula for Thermal Stability (Tm) Prediction of PNA/DNA Duplexes. Nucleic Acids Res. 1998, 26 (21), 5004-5006. [PubMed: 9776766]

(49). Sahu B; Sacui I; Rapireddy S; Zanotti KJ; Bahal R; Armitage BA; Ly DH Synthesis and Characterization of Conformationally Preorganized, (R)-Diethylene Glycol-Containing $\gamma$-Peptide Nucleic Acids with Superior Hybridization Properties and Water Solubility. J. Org. Chem 2011, 76 (14), 5614-5627. [PubMed: 21619025]

(50). Wengel J Synthesis of 3'-C-and 4'-C-Branched Oligodeox-ynucleotides and the Development of Locked Nucleic Acid (LNA). Acc. Chem. Res 1999, 32 (4), 301-310.

(51). Koshkin AA; Nielsen P; Meldgaard M; Rajwanshi VK; Singh SK; Wengel J LNA (locked Nucleic Acid): An RNA Mimic Forming Exceedingly Stable LNA: LNA Duplexes. J. Am. Chem. Soc 1998, 120 (50), 13252-13253.

(52). Smith GJ; Sosnick TR; Scherer NF; Pan T Efficient Fluorescence Labeling of a Large RNA through Oligonucleotide Hybridization. RNA 2005, 11 (2), 234-239. [PubMed: 15613536] 
a. Triplex hybridization of bPNA with oligo T/U nucleic acids can fold unstructured domains

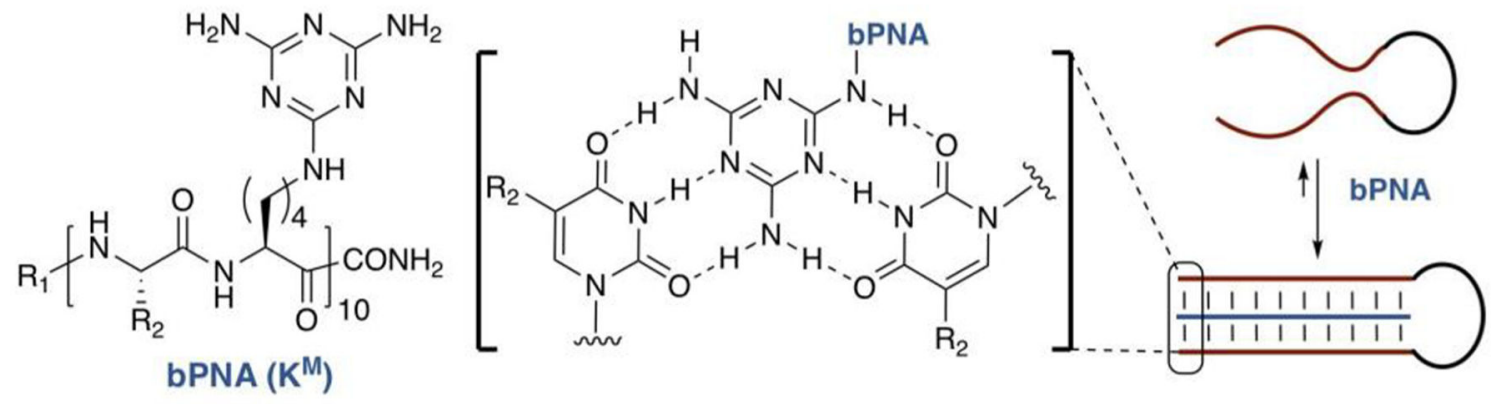

\section{b. This work}

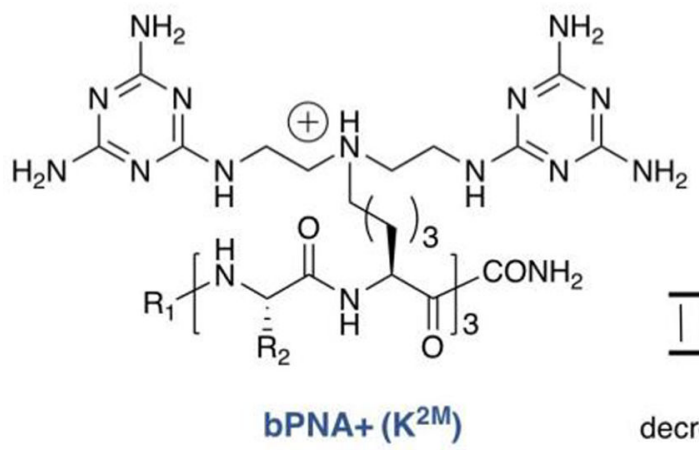
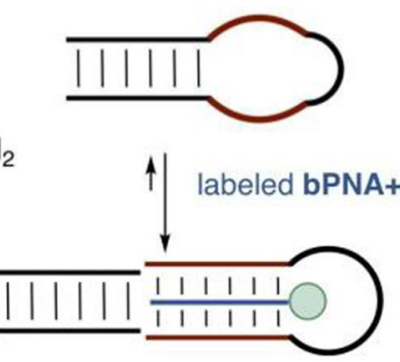

decreased RNA binding footprint
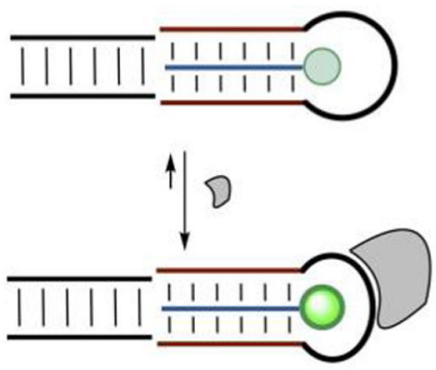

label reports RNA loop binding

Figure 1.

(a) Prior work on bPNA (blue) utilized a single melamine base on a lysine side chain $\left(\mathrm{K}^{\mathrm{M}}\right)$ that forms a base triple with two thymine $\left(\mathrm{R}_{2}=\mathrm{CH}_{3}\right)$ or uracil $\left(\mathrm{R}_{2}=\mathrm{H}\right)$ bases. Incubation of a bPNA with 10 repeats can fold with 10 mer $\mathrm{T} / \mathrm{U}$ domains (red, eg-d $\mathrm{T}_{10} \mathrm{C}_{4} \mathrm{~T}_{10}$ ) linked by a non-T/U linker (black) to form a triplex hybrid stem. (b) This work describes the display of two melamine bases per lysine side chain $\left(\mathrm{K}^{2 \mathrm{M}}\right)$ to yield bPNA+, which can fold with internal oligo-U6 domains to form triplex hybrid stem loops with approximately half the binding footprint of a $\mathrm{K}^{\mathrm{M}}$ bPNA. Use of bPNA $+N$-terminally capped with fluorescent dyes $\left(\mathrm{R}_{1}=\mathrm{Cbf}, \mathrm{Cy} 3, \mathrm{Cy} 5\right)$ results in labeled RNA loops sensitive to tertiary RNA interactions with RNA or proteins (gray). 

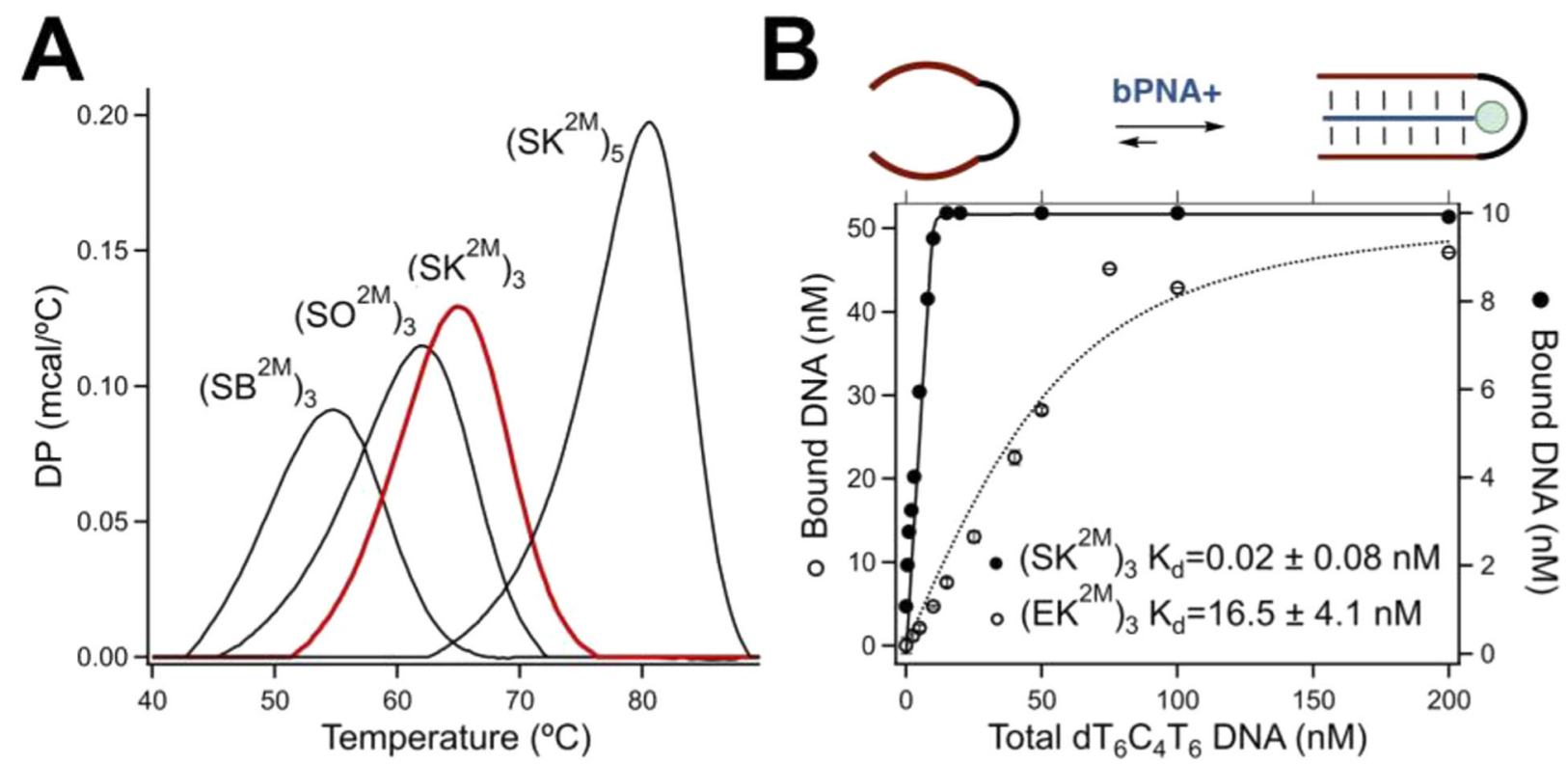

Figure 2.

(A) DSC traces of serine bPNA(+) complexes with $\mathrm{dT}_{6} \mathrm{C}_{4} \mathrm{~T}_{6} \mathrm{DNA}$ at 1:1 stoichiometry, as labeled, at $25 \mu \mathrm{M}$ DNA and bPNA+; $\left(\mathrm{SK}^{2 \mathrm{M}}\right)_{5}$ is complexed with $\mathrm{dT}_{10} \mathrm{C}_{4} \mathrm{~T}_{10}$. The $\left(\mathrm{SK}^{2 \mathrm{M}}\right)_{3}$ trace is highlighted in red. All experiments were carried out in DPBS pH 7.4. (B) (Top) Illustration of hexapeptide bPNA(+) hybridizing with $\mathrm{dT}_{6} \mathrm{C}_{4} \mathrm{~T}_{6}$ DNA with T-domains shown as red lines. (Lower) Binding isotherms of FITC-labeled bPNA+ (blue line) and $\mathrm{dT}_{6} \mathrm{C}_{4} \mathrm{~T}_{6}$. Isotherms acquired by fluorescence anisotropy $\left(\mathrm{EK}^{2 \mathrm{M}}\right)_{3}$ and electrophoretic mobility shift assay $\left(\mathrm{SK}^{2 \mathrm{M}}\right)_{3}$. DNA concentration is $50 \mathrm{nM}$ with $\left(\mathrm{EK}^{2 \mathrm{M}}\right)_{3}(\mathrm{O})$ and $10 \mathrm{nM}$ with $\left(\mathrm{SK}^{2 \mathrm{M}}\right)_{3}$ $(\cdot)$. 

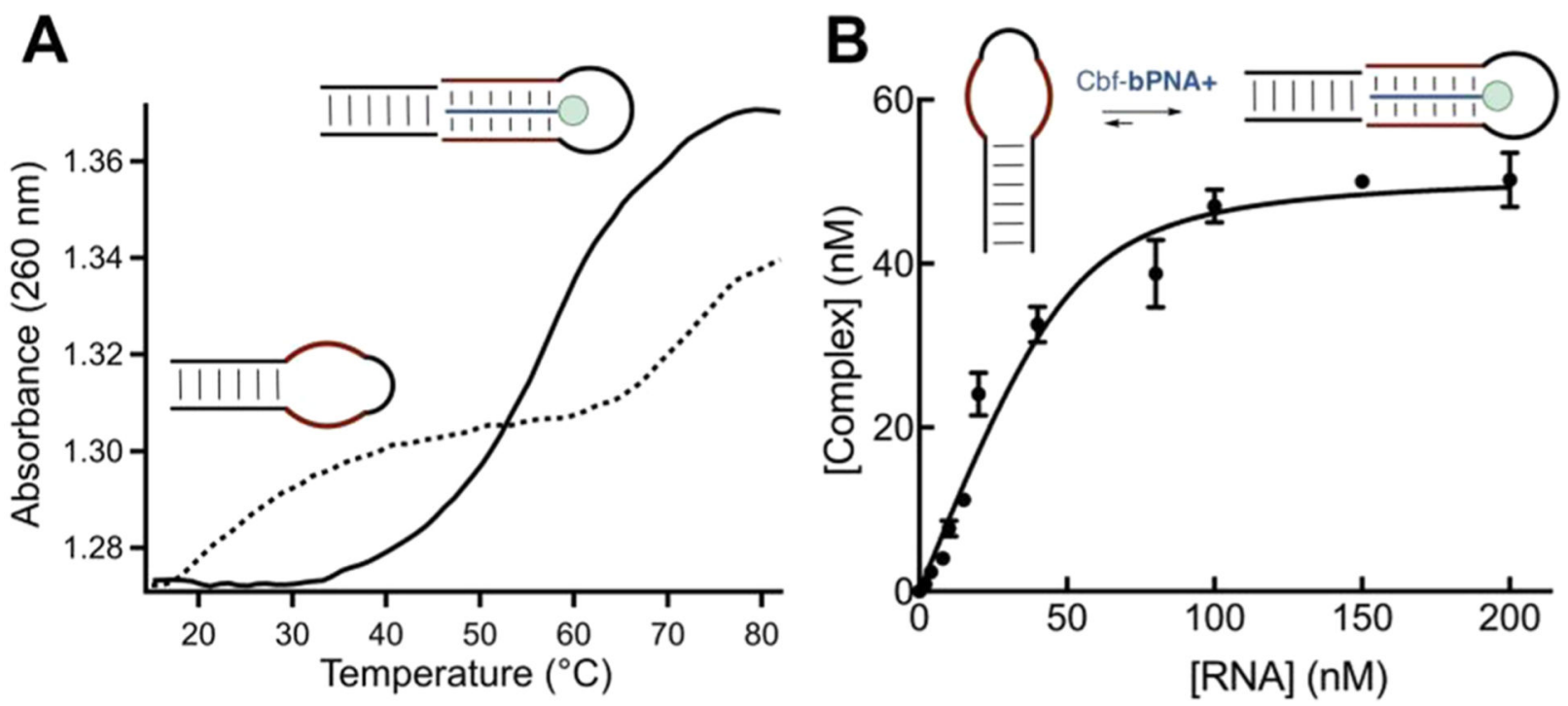

Figure 3.

(A) Thermal denaturation of RNA1-U6 hairpin alone (---) and with 1 equiv of $\mathrm{Cbf}-\left(\mathrm{SK}^{2 \mathrm{M}}\right)_{3}$ (-). Melts were carried out at $2 \mu \mathrm{M}$ RNA in DPBS, pH 7.4. RNA1-U6: $5^{\prime}$ GGCAGCUUUUUUUUGGUAGUUUUUUGCUGCC-3' . (B) RNA-binding isotherms in triplicate derived from electrophoretic mobility shift experiments of carboxyfluoresceinlabeled $\left(\mathrm{SK}^{2 \mathrm{M}}\right)_{3}$ and RNA1-U6 with 1:1 fit are shown $\left(K_{\mathrm{d}}=6.5 \pm 4.1 \mathrm{nM}\right)$. 


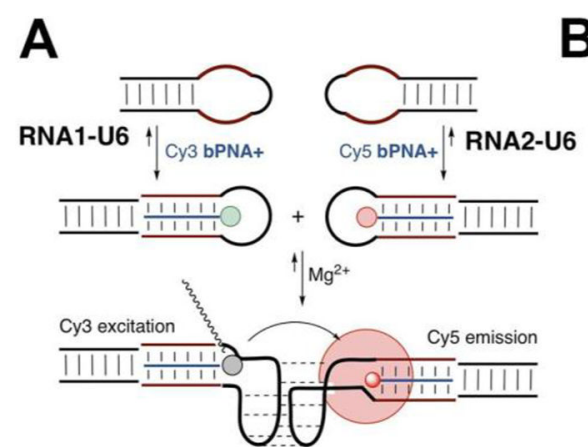

B

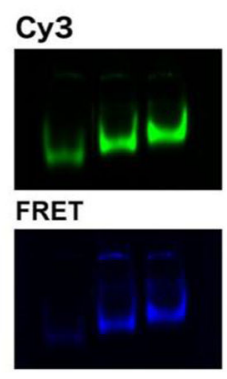

C

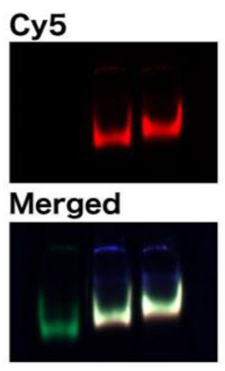

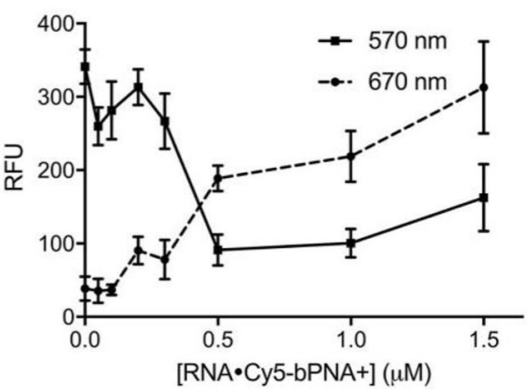

Figure 4.

(A) Illustration of FRET-sensitive RNA kissing complex formation enabled by Cy3 (green) and $\mathrm{Cy} 5$ (red) labeled ( $\left.\mathrm{SK}^{2 \mathrm{M}}\right)_{3}$ bPNA+ (blue strands) that complex with RNA1 and RNA2 ColE1-derived hairpins containing $\mathrm{U}_{6}$ domains (red lines). RNA1-U6: $5^{\prime}$ GGCAGCUUUUUUUUGGUAGUUUUUUGCUGCC-3'; RNA2-U6: $5^{\prime}$ GGCACCGUUUUUUCUACCAAUUUUUUCGGUGCC-3' ${ }^{\prime}$. (B) Polyacrylamide gel under kissing complex conditions with the following in each lane from left to right: [RNA2U6.Cy3-(SK $\left.{ }^{2 \mathrm{M}}\right)$ ] alone; at 1:1 ratio, [RNA2-U6.Cy3-(SK $\left.{ }^{2 \mathrm{M}}\right)$ ], [RNA1-U6.Cy5-(SK $\left.{ }^{2 \mathrm{M}}\right)$ ]; at 1:1:1 ratio [RNA2-U6·Cy3-(SK $\left.{ }^{2 \mathrm{M}}\right)$ ], [RNA1-U6·Cy5-( $\left.\mathrm{SK}^{2 \mathrm{M}}\right)$ ], Rop. As indicated, gel was imaged by $\mathrm{Cy} 3$ excitation and emission (Cy3), Cy5 excitation and emission (Cy5), Cy3 excitation and Cy5 emission (FRET), and the merged channels (Merged). (C) With Cy3 excitation only, Cy3 fluorescence $(570 \mathrm{~nm}, \mathbf{\square})$ from [RNA2-U6·Cy3-(SK $\left.\left.{ }^{2 \mathrm{M}}\right)\right]$ decreases upon addition of [RNA1-U6.Cy5-(SK $\left.{ }^{2 \mathrm{M}}\right)$ ] complex, while Cy5 emission (670 nm, -0-) increases. 
bPNA+/RNA1-U6

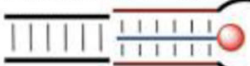

$\mathrm{Mg}^{2+}$

$+$

$\underset{ }{\longrightarrow}$
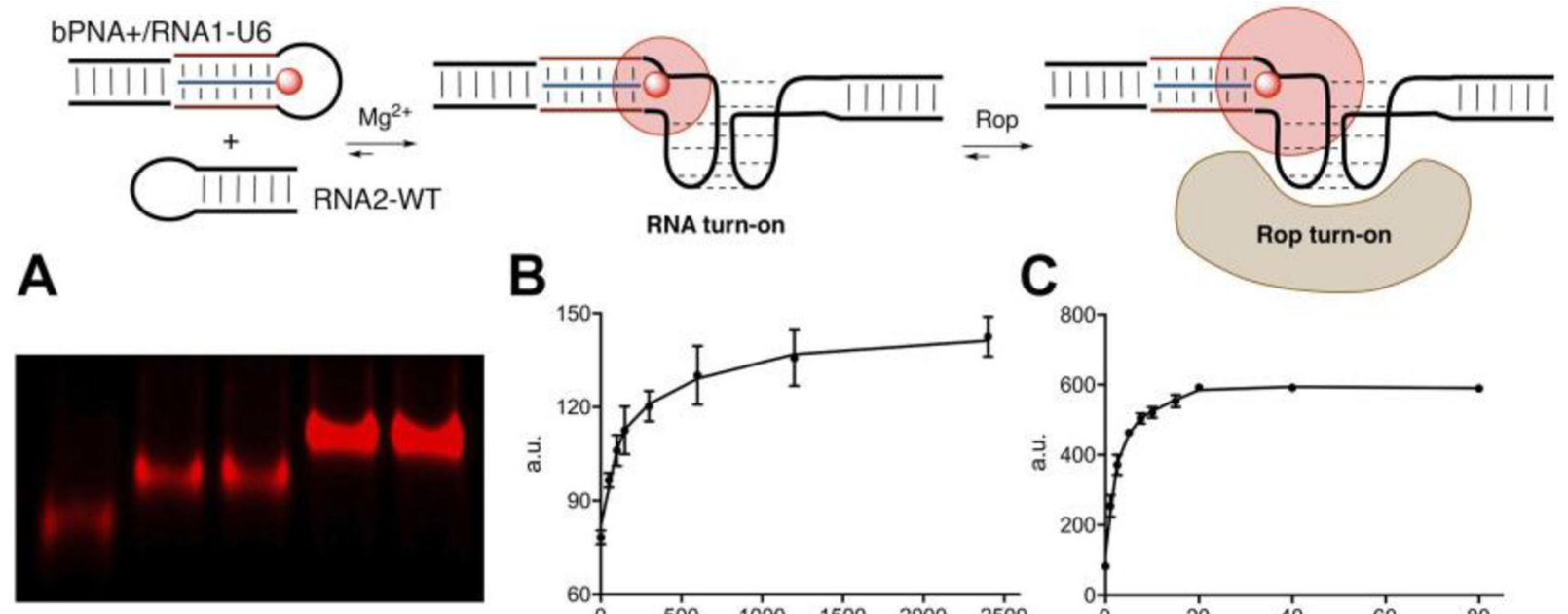

RNA turn-on
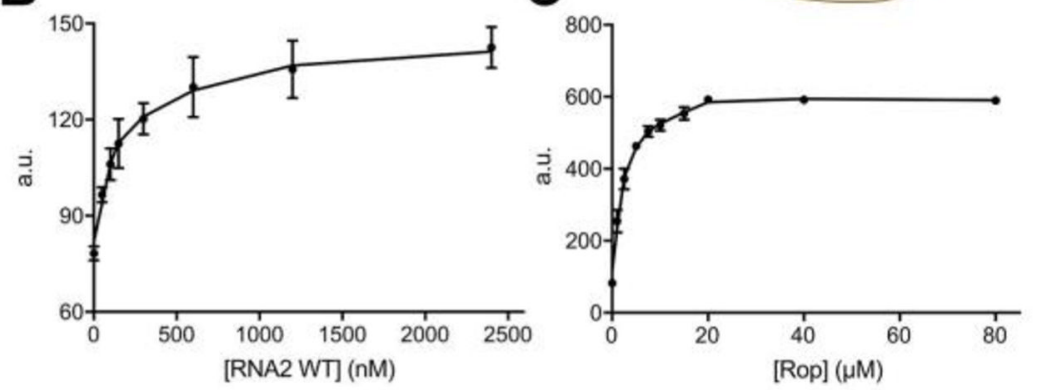

Figure 5.

(Top, left) Illustration of Cy5 emission turn-on from (left) [Cy5-(SK $\left.\left.{ }^{2 \mathrm{M}}\right) 3 \cdot \mathrm{RNA} 1-\mathrm{U} 6\right]$ complex (U6 = red) engaging with wild-type stem-loop RNA2 to form (middle) a kissing loop dimer which then binds Rop protein (right). RNA1-U6: 5' GGCAGCUUUUUUUUGGUAGUUUUUUGCUGCC- ${ }^{\prime}$; RNA2-WT: $5^{\prime}$ -

GCACCGCUACCAACGGUGC- $3^{\prime}$. (A) Native polyacrylamide gel imaged by Cy 5 fluorescence also indicates an increase in emission (from left) of $500 \mathrm{nM}$ [Cy5$\left(\mathrm{SK}^{2 \mathrm{M}}\right)_{3} \cdot \mathrm{RNA1-U6]}$ (lane 1), [Cy5-( $\left.\left.\mathrm{SK}^{2 \mathrm{M}}\right)_{3} \cdot \mathrm{RNA} 1-\mathrm{U} 6\right]$ with $500 \mathrm{nM}$ (lane 2), and $1 \mu \mathrm{M}$ (lane 3) wild-type RNA2; [Cy5-(SK $\left.{ }^{2 \mathrm{M}}\right)_{3}$.RNA1-U6] kissing complex with RNA2 at $500 \mathrm{nM}$ with $5 \mu \mathrm{M}$ (lane 4) and $10 \mu \mathrm{M}$ (lane 5) Rop protein. Solution experiments confirm increases in Cy5 emission in (B) [Cy5-( $\left.\left.\mathrm{SK}^{2 \mathrm{M}}\right) 3 \cdot \mathrm{RNA} 1-\mathrm{U} 6\right]$ as a function of RNA2 WT concentration and $(\mathrm{C})$ the kissing loop complex as a function of Rop protein concentration. 


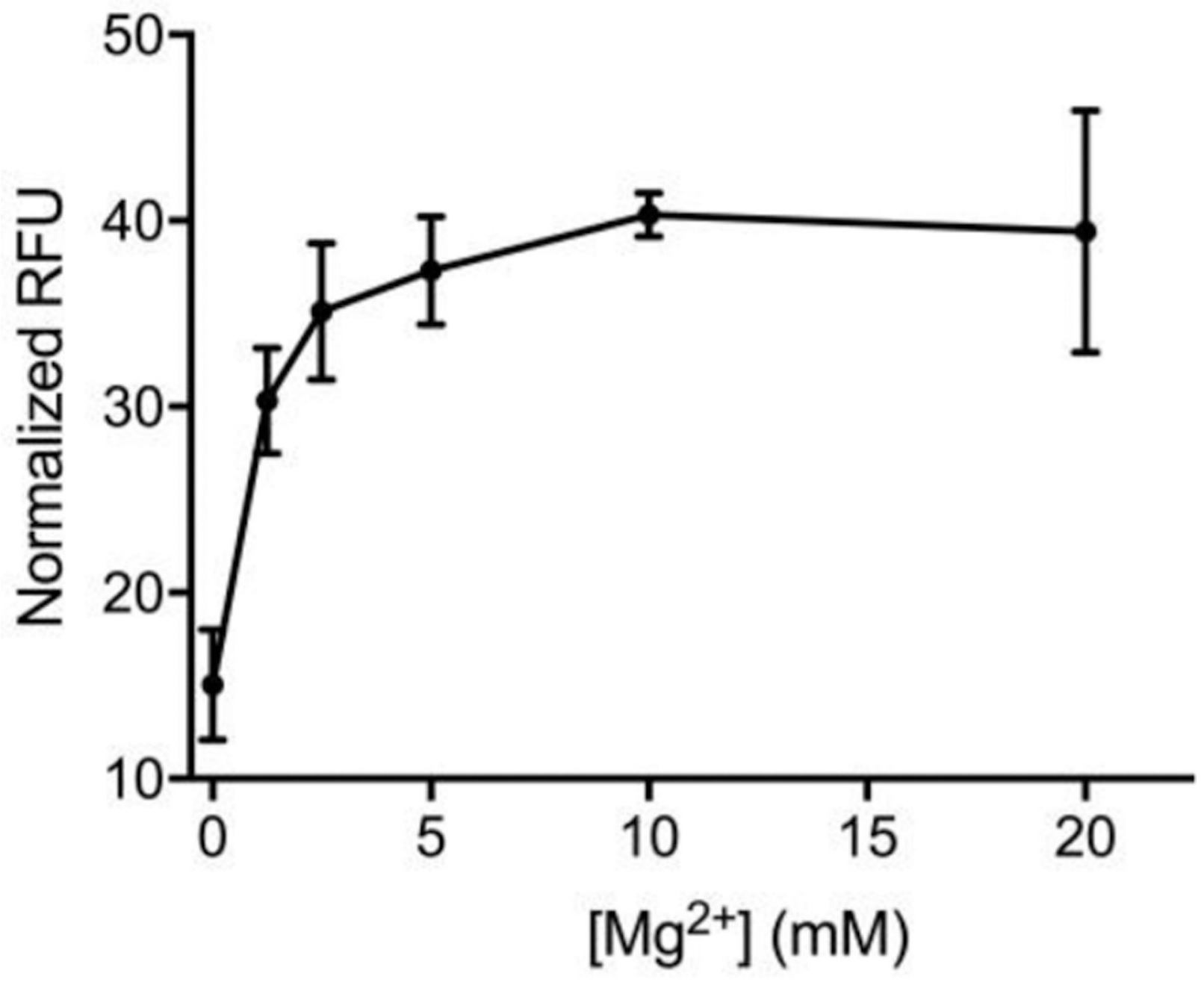

Figure 6.

FRET signal from bPNA+ bound TL/TLR RNA (Scheme 2) as a function of magnesium concentration from 0 to $20 \mathrm{mM}$. Magnesium solution was added to the preformed bPNA+ complex with RNA and incubated for 30 min prior to reading data. Triplicate data and corresponding standard deviation error bars are shown. 


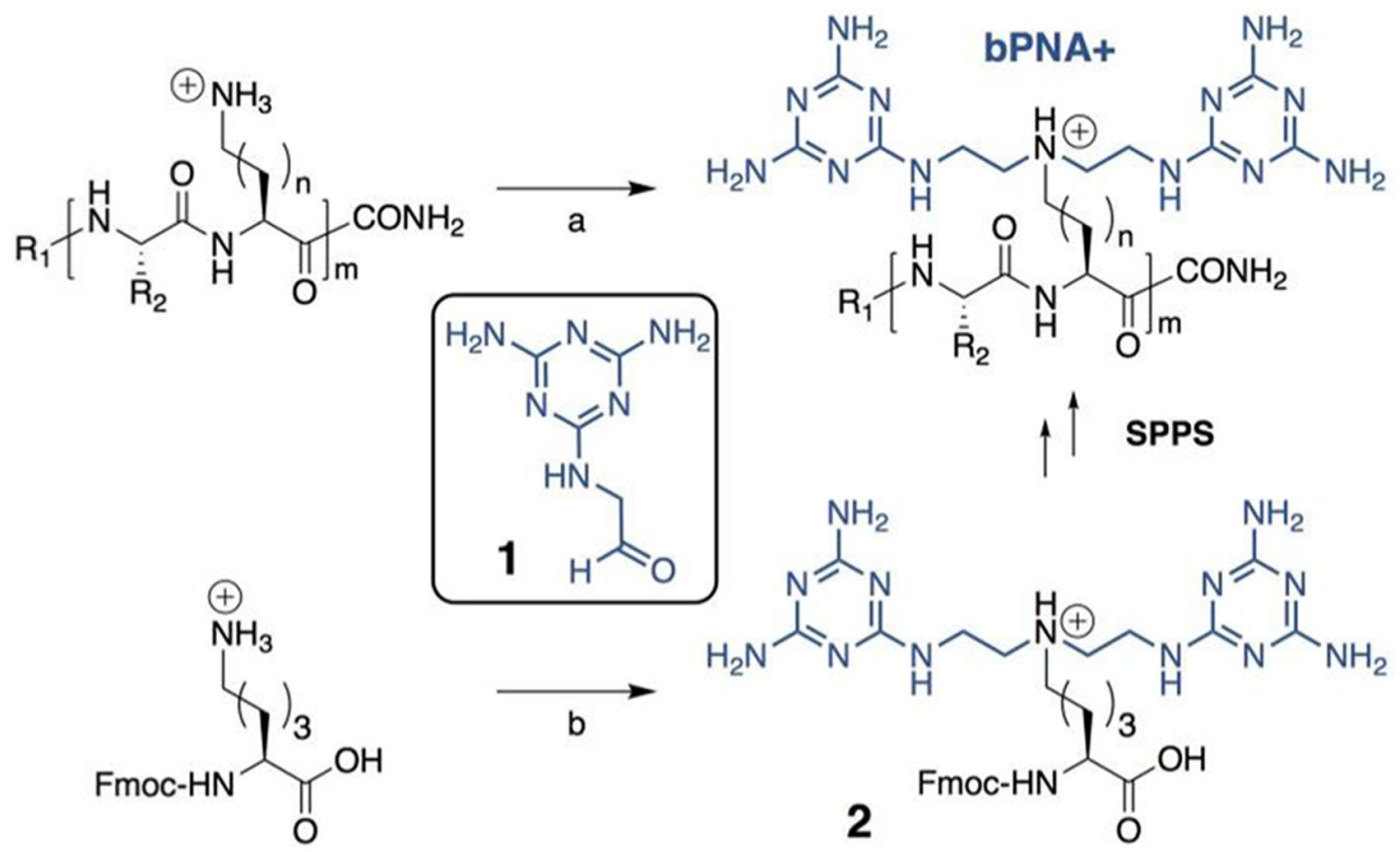

Scheme 1. Reductive Alkylation of Peptides with Amino Side Chains at Alternate Positions ${ }^{a}$ ${ }^{a}$ Conditions (a): 1, $\mathrm{NaBH}_{3} \mathrm{CN}$, DMSO. Peptides were prepared with $\mathrm{Ser}\left(\mathrm{R}_{2}=\mathrm{CH}_{2} \mathrm{OH}\right)$ or Glu $\left(\mathrm{R}_{2}=\left(\mathrm{CH}_{2}\right)_{2} \mathrm{CO}_{2} \mathrm{H}\right)$ in the first position and diaminobutyric acid $(\mathrm{B}, n=1)$, ornithine $(\mathrm{O}$, $n=2)$, and lysine (K, $n=3$ ) in the second position. All peptides were made with $m=3$ and $m=5$ peptides were prepared with Ser (S) and Glu (E) in the first position and lysine (K) in the second position. (Lower) Fmoc-Lys-OH was prepared as the TFA salt from FmocLys(Boc) and reductively alkylated to yield compound 2 (Fmoc- $\left.\mathrm{K}^{2 \mathrm{M}}-\mathrm{OH}\right)$ using condition (b): $\mathbf{1}, \mathrm{NaBH}_{3} \mathrm{CN}, \mathrm{MeOH},(83 \%)$ and used in standard solid phase peptide synthesis (SPPS) directly to produce the $\left(\mathrm{SK}^{2 \mathrm{M}}\right)_{3}$ and $\left(\mathrm{EK}^{2 \mathrm{M}}\right)_{3}$ peptides. 


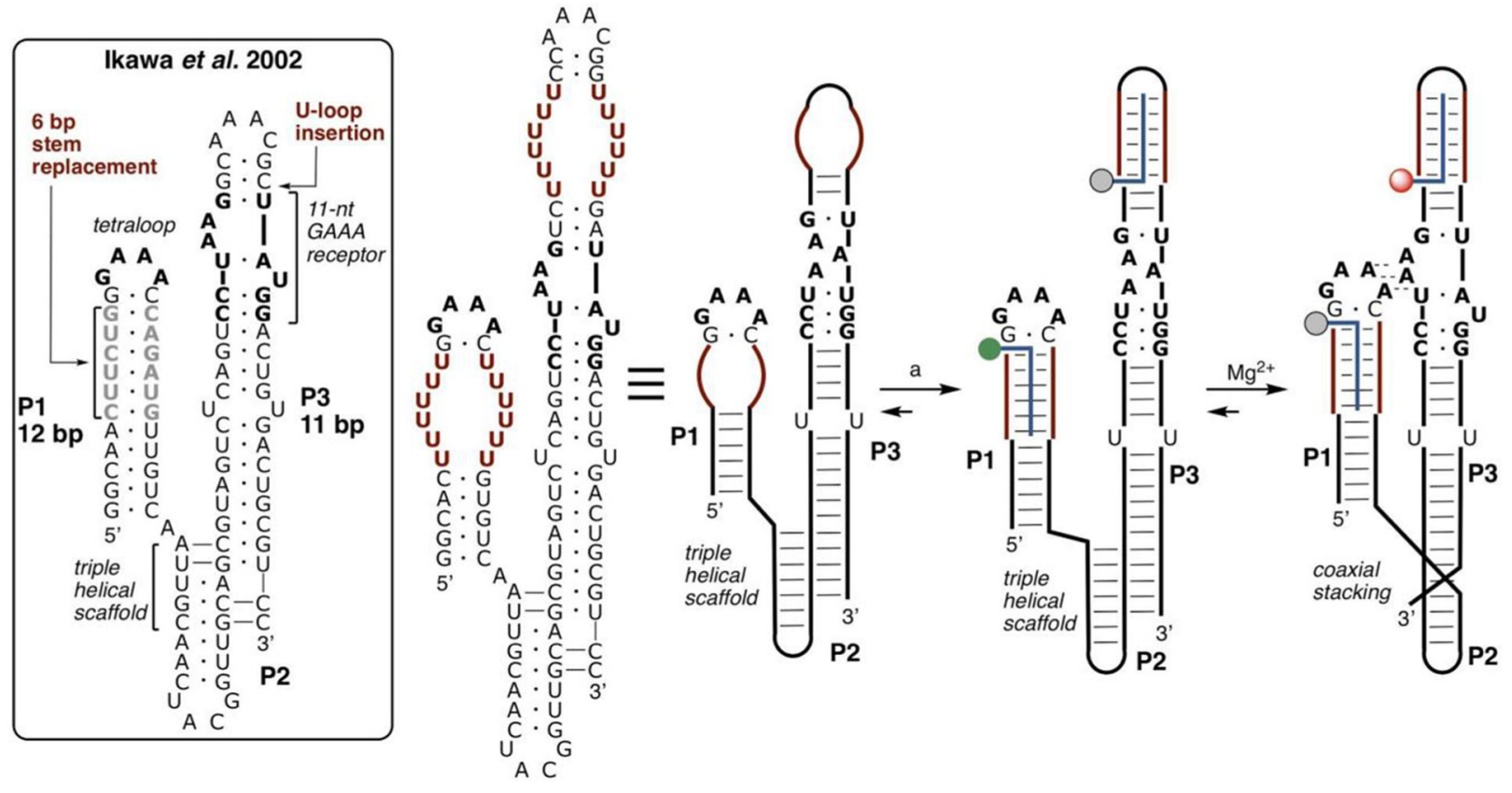

Scheme 2. Design of Self-Folding RNA from Ikawa et al. ${ }^{45}$ with Structural Elements Taken from the Tetrahymena Group I Ribozyme Indicated: GAAA Tetraloop and 11-nt Tetraloop Receptor and Triple Helical Scaffold ${ }^{a}$

${ }^{a}$ The 6 bp stem (grey) selected for stem replacement is indicated along with the site for insertion of a U-loop for bPNA binding. The resulting sequence and the simplified structural representation is shown to the right. (a) $\mathrm{Cy} 3-\left(\mathrm{SK}^{2 \mathrm{M}}\right)_{3}$ and $\mathrm{Cy} 5-\left(\mathrm{SK}^{2 \mathrm{M}}\right)_{3}$ were added sequentially to the RNA in a 1:1:1 ratio with a final concentration of $500 \mathrm{nM}$ using a $20 \mathrm{~min}$ incubation time for each peptide addition step in 10× folding buffer (500 mM HEPES pH 7.5, $1 \mathrm{M} \mathrm{NaCl})$. 
Table 1.

DNA $^{a}$ Hybridization Data for bPNA ${ }^{b}$ and bPNA+

\begin{tabular}{lccl}
\hline \multicolumn{1}{c}{ peptides $^{b}$} & hybrid $\boldsymbol{T}_{\mathbf{m}}\left({ }^{\circ} \mathbf{C}\right)^{\boldsymbol{c}}$ & $\Delta \boldsymbol{H}_{\mathbf{d}}(\mathbf{k c a l} / \mathbf{m o l})$ & $\boldsymbol{K}_{\mathbf{d}}(\mathbf{n M})$ \\
$\left(\mathrm{EK}^{\mathrm{M}}\right)_{6}$ & 38 & 127 & 32 \\
$\left(\mathrm{~EB}^{2 \mathrm{M}}\right)_{3} /\left(\mathrm{SB}^{2 \mathrm{M}}\right)_{3}$ & $48 / 55$ & $95 / 84$ & $13 / 0.2^{d}$ \\
$\left(\mathrm{EO}^{2 \mathrm{M}}\right)_{3} /\left(\mathrm{SO}^{2 \mathrm{M}}\right)_{3}$ & $58 / 62$ & $102 / 111$ & $6 / 0.2^{d}$ \\
$\left(\mathrm{EK}^{2 \mathrm{M}}\right)_{3} /\left(\mathrm{SK}^{2 \mathrm{M}}\right)_{3}$ & $60 / 65$ & $119 / 116$ & $16 / 0.02^{d}$ \\
$\left(\mathrm{EK}^{2 \mathrm{M}}\right)_{5} /\left(\mathrm{SK}^{2 \mathrm{M}}\right)_{5}$ & $69 / 78$ & $191 / 147$ & $0.06 / 0.01^{d}$ \\
\hline
\end{tabular}

${ }^{a}$ DNA was $\mathrm{dT}_{6} \mathrm{C}_{4} \mathrm{~T}_{6}$ for all samples except $\left(\mathrm{EK}^{2 \mathrm{M}}\right) 5$ and $\left(\mathrm{SK}^{2 \mathrm{M}}\right) 5$, which used $\mathrm{dT}_{10} \mathrm{C}_{4} \mathrm{~T}_{10}$.

$b_{\left(\mathrm{EK}^{\mathrm{M}}\right) 6}$ is bPNA while all others are bPNA+.

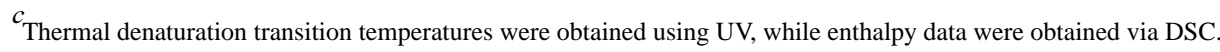

${ }^{d}$ Apparent $K_{\mathrm{d}}$. Though data were highly reproducible and fit well to a 1:1 model, the lowest DNA concentration possible was well above fitted $K_{\mathrm{d}}$

$(10 \mathrm{nM})$, leading to possible inaccuracies in $K_{\mathrm{d}}$. All experimental conditions and full structures are provided in Supporting Information. $\mathrm{B}^{2 \mathrm{M}}$,

$\mathrm{O}^{2 \mathrm{M}}$, and $\mathrm{K}^{2 \mathrm{M}}$ indicate the amino acids 2-aminobutyric acid, ornithine, and lysine doubly alkylated on the side chain with an ethyl-melamine group (Scheme 1). 